\title{
$\pi$-Conjugated Organometallic Isoindigo Oligomer and Polymer Chromophores: Singlet and Triplet Excited State Dynamics and Application in Polymer Solar Cells
}

\section{Supporting Information}

Subhadip Goswami, ${ }^{\dagger}$ Melissa K. Gish, ${ }^{\star}$ Jiliang Wang, ${ }^{\dagger}$ Russell W. Winkel, ${ }^{\dagger}$ John M. Papanikolas, ${ }^{\star}$ and Kirk S. Schanze* ${ }^{*}$

$\dagger$ Department of Chemistry and Center for Macromolecular Science and Engineering, University of Florida, P.O. Box 117200, Gainesville, Florida 32611-7200, United States

$\$$ Department of Chemistry, University of North Carolina at Chapel Hill, Chapel Hill, North Carolina 27599, United States

K.S.S.: e-mail kschanze@chem.ufl.edu, Tel 352-392-9133.

\# These authors contributed equally to the work. 
I. General methods for synthesis. All the reactions were performed under an argon atmosphere and tetrahydrofuran (THF) used for the reactions was dried using solvent purification columns (Glass Contour). All the other solvents for the reaction were used without any purification unless otherwise mentioned. The synthesis of $\mathbf{P t}(\mathbf{a c a c})$-octyl and $\mathbf{1 1}$ were performed by following the scheme S1 and scheme S2 respectively. The synthesis of $\mathbf{1 , 2 , 3}$ and $\mathbf{5}$ were performed by literature procedures. ${ }^{1,2}$ For polymerization reaction, the dibromo ligand $\mathbf{1 0}$ was synthesized by following a literature procedure. ${ }^{3}$ The starting materials 1 and $\mathbf{2}$ were obtained from TCI America. The synthesis of metal complexes and the polymer were accomplished by following scheme S3. The soluble derivative with 2-ethylhexyl chain Iin-C8 were synthesized by following literature procedure. $^{4}$ The isoindigo precursor with solubilizing octyldodecyl chain Iin-C18, was synthesized according to the reported procedure. ${ }^{5} \mathrm{Pd}_{2}\left(\mathrm{dba}_{3}\right)_{3}, \mathrm{Pd}\left(\mathrm{P}^{t} \mathrm{Bu}_{3}\right)_{2}$, Potassium phosphate tribasic were purchased from Sigma Aldrich and used as received.

\section{Synthetic procedures and scheme.}



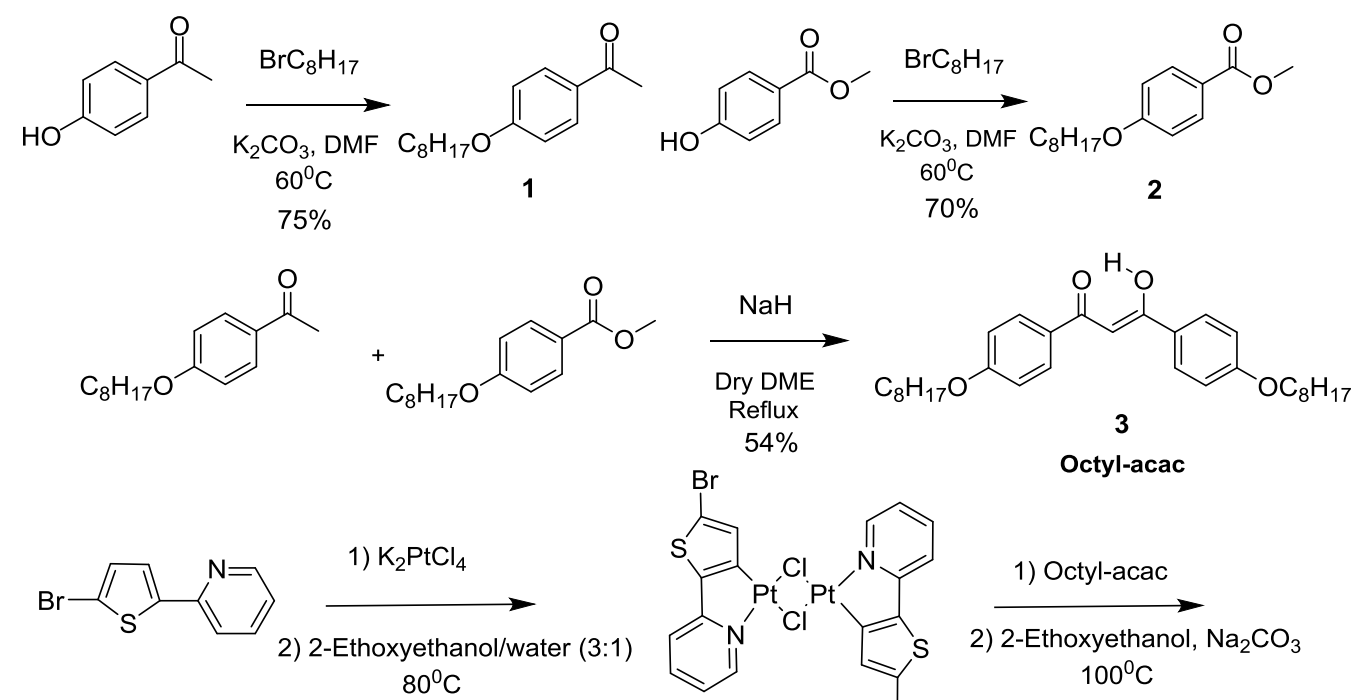

4
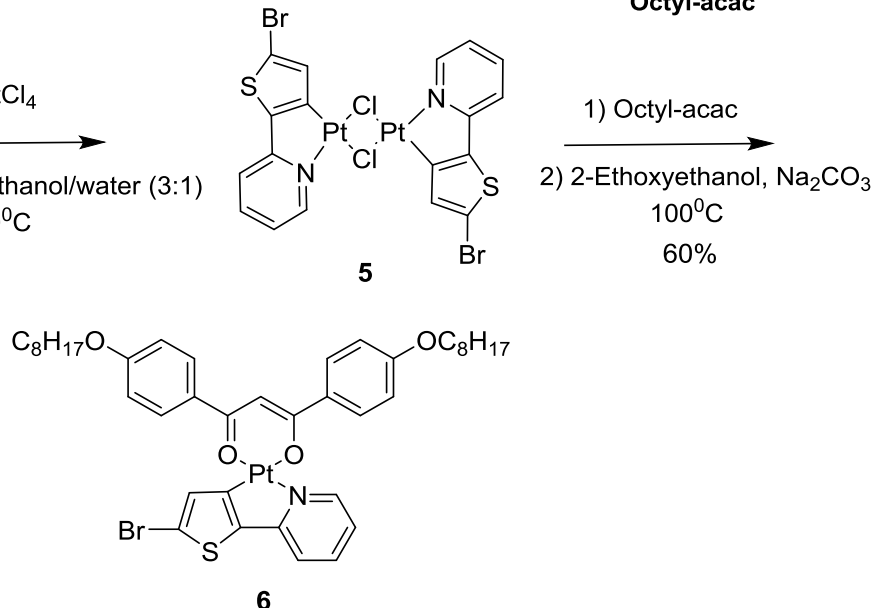

Pt(acac)-Octyl

Scheme S1. Synthesis of $\operatorname{Pt}(\mathbf{a c a c})-$ octyl.

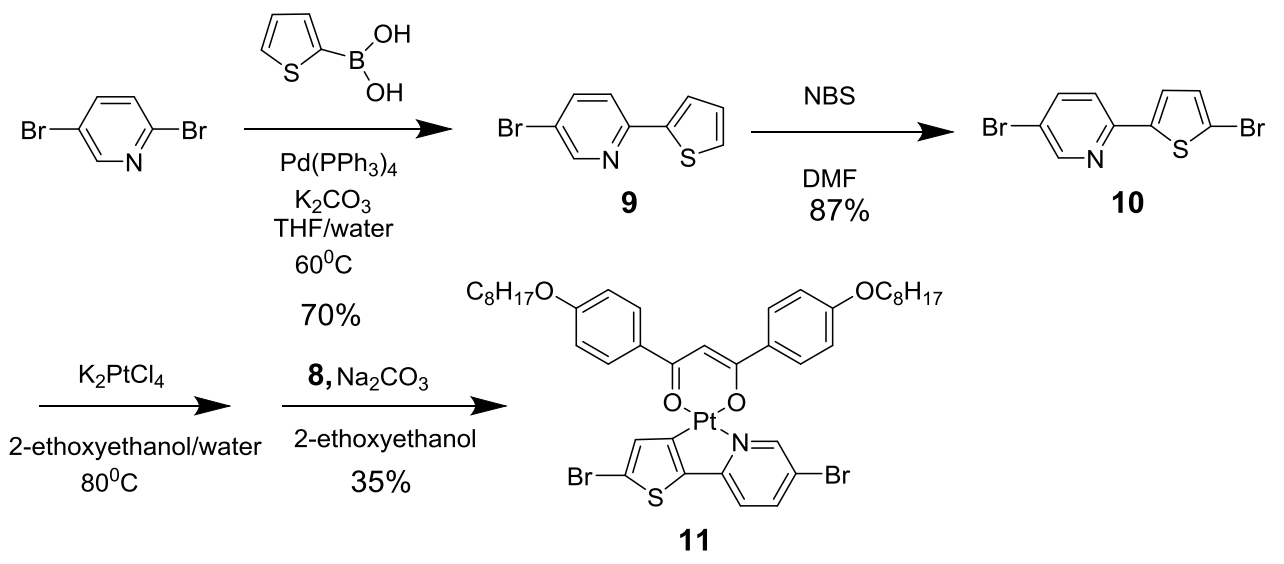

Scheme S2. Synthesis of platinum precursor 11 for polymerization reaction. 


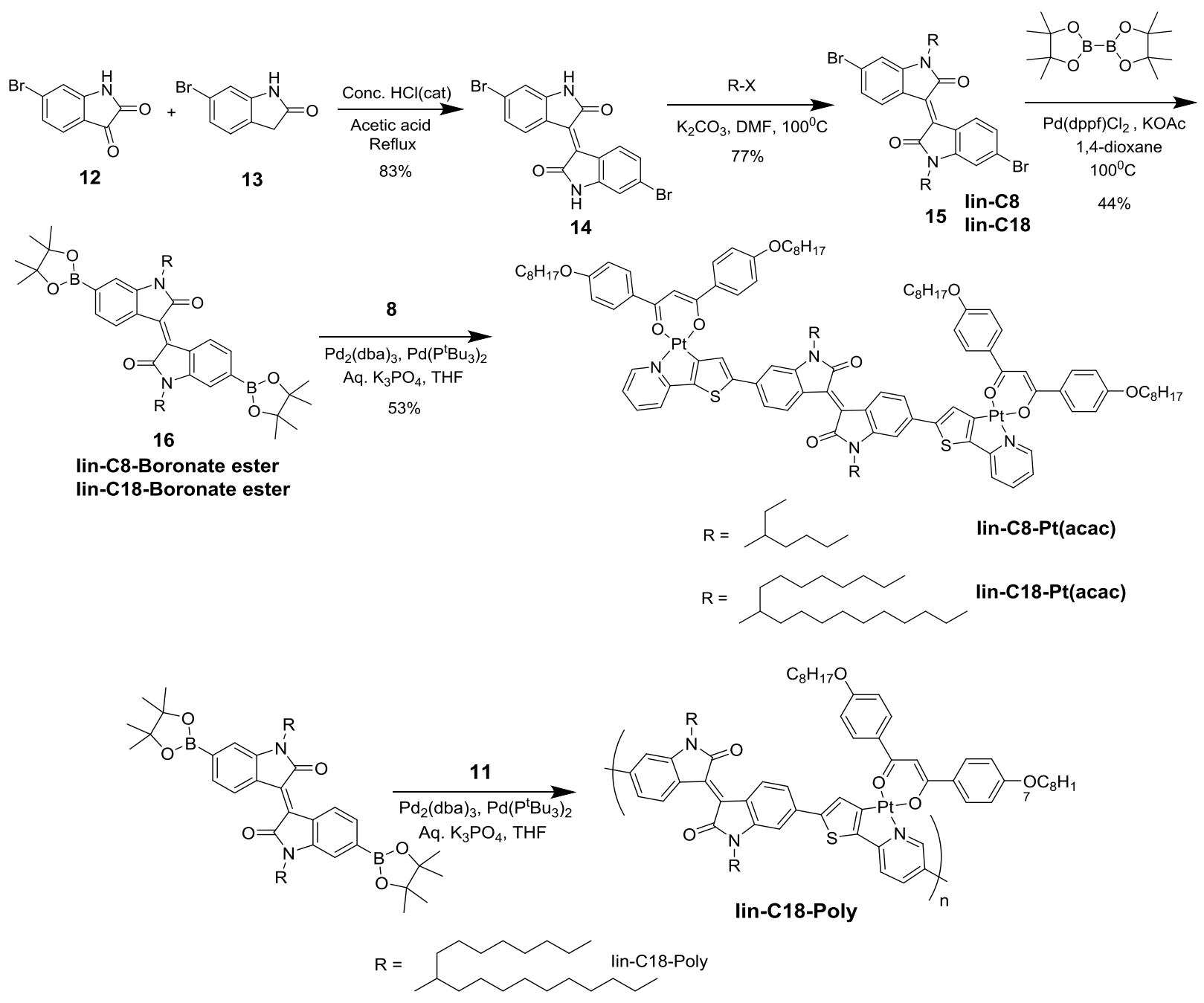

Scheme S3. Synthesis of the metal complexes and polymer.

\section{Synthesis of Pt(acac)-Octyl.}

In a three-neck round bottom flask a solution of 2-(5-bromo-2-thienyl)pyridine (4) (0.614 g, $2.56 \mathrm{mmol}) \mathrm{K}_{2} \mathrm{PtCl}_{4}(0.506 \mathrm{~g}, 1.24 \mathrm{mmol})$ in 2-ethoxyethanol $(15 \mathrm{~mL})$ and water $(5 \mathrm{~mL})$ was deoxygenated by purging argon for 45 minutes. After that, it was heated under an argon atmosphere at $80^{\circ} \mathrm{C}$ for 24 hours. It was cooled down to room temperature and the bright yellow precipitate was filtered off. The precipitate was washed with copious amount of water and dried under vacuum to obtain the dichloro bridged dimer (intermediate). The dimer ( $0.35 \mathrm{~g}, 0.37 \mathrm{mmol})$, 
Octyl-acac $(0.54 \mathrm{~g}, 1.12 \mathrm{mmol})$ and anhydrous $\mathrm{Na}_{2} \mathrm{CO}_{3}(0.395 \mathrm{~g}, 3.73 \mathrm{mmol})$ were taken in 20 $\mathrm{mL}$ of dry 2-ethoxyethanol solvent. The yellow solution was deoxygenated with argon for 45 minutes and heated to $100^{\circ} \mathrm{C}$ for 24 hours. After the complete consumption of the dimer, the reaction mixture was cooled down to room temperature and poured into water. The compound was extracted by using dichloromethane. The dichloromethane layer was collected and dried over anhydrous $\mathrm{Na}_{2} \mathrm{SO}_{4}$. It was filtered and evaporated to obtain the crude product. Further purification by silica gel column chromatography using dichloromethane/hexane (1:1) eluent afforded the title compound in $60 \%$ yield $(204 \mathrm{mg}) .{ }^{1} \mathrm{H}$ NMR $\left(300 \mathrm{MHz}, \mathrm{CDCl}_{3}\right): \delta 8.93(\mathrm{~d}, 1 \mathrm{H}, \mathrm{J}=5.4 \mathrm{~Hz}), 7.98$ (d, 4H, 8.6 Hz), 7.68 (t, 1H, 6.1 Hz), $7.21(\mathrm{~s}, 1 \mathrm{H}), 7.18(\mathrm{~d}, 1 \mathrm{H}, 7.9 \mathrm{~Hz}), 6.97-6.94(\mathrm{~m}, 5 \mathrm{H}), 6.67$ (s, 1H), $4.04(\mathrm{t}, 4 \mathrm{H}, 6.5 \mathrm{~Hz}), 1.87-1.79(\mathrm{~m}, 4 \mathrm{H}), 1.49-1.31(\mathrm{~m}, 20 \mathrm{H}), 0.90(\mathrm{t}, 6 \mathrm{H}, 6.4 \mathrm{~Hz}) .{ }^{13} \mathrm{C}$ $\operatorname{NMR}\left(125 \mathrm{MHz}, \mathrm{CDCl}_{3}\right) \delta: 177.92,117.03,163.58,161.5(\mathrm{~d}, \mathrm{~J}=9.8 \mathrm{~Hz}), 147.16,145.02,140.00$, 138.54, 133.03, 131.99, 130.99, $128.81(\mathrm{~d}, \mathrm{~J}=5.1 \mathrm{~Hz}), 118.63,116.99,114.31(\mathrm{~d}, \mathrm{~J}=3.0 \mathrm{~Hz})$, 95.48, 68.23, 31.84, 29.39, 29.27, 29.22, 26.06, 22.68, 14.12. Calculated for $\mathrm{C}_{40} \mathrm{H}_{48} \mathrm{BrNO}_{4} \mathrm{PtS}$ 913.88, found ESI-MS (m/z): $936.20[\mathrm{M}+\mathrm{Na}]^{+}$.

\section{Synthesis of 11 .}

In a three-neck flask, $10(1 \mathrm{~g}, 3.13 \mathrm{mmol})$ and $\mathrm{K}_{2} \mathrm{PtCl}_{4}(0.62 \mathrm{~g}, 1.5 \mathrm{mmol})$ were dissolved in 15 $\mathrm{mL}$ of 2-ethoxyethanol and $5 \mathrm{~mL}$ of deionized water. The yellow reaction mixture was deoxygenated by bubbling argon for 45 minutes. It was then heated to $80^{\circ} \mathrm{C}$ and stirred under an argon atmosphere overnight. The reaction mixture was then cooled down to room temperature. The Pt(II) dichloro bridged dimer was then filtered off and subsequently washed with water and methanol. The product was dried under vacuum for 24 hours and used in the next step without any further purification. In the next step, the dimer $(1 \mathrm{~g}, 0.91 \mathrm{mmol})$, Octyl-acac $(1.3 \mathrm{~g}, 2.73 \mathrm{mmol})$ and anhydrous $\mathrm{Na}_{2} \mathrm{CO}_{3}(0.627 \mathrm{~g}, 5.91 \mathrm{mmol})$ were combined in $50 \mathrm{~mL}$ of anhydrous 2- 
ethoxyethanol. The reaction mixture was deoxygenated by purging with argon for 45 minutes and subsequently heated to $100^{\circ} \mathrm{C}$ for 24 hours. It was cooled down to room temperature and poured over water. The product was extracted with dichloromethane. The organic layer was collected, washed with water and brine three times. After drying the organic layer over anhydrous $\mathrm{Na}_{2} \mathrm{SO}_{4}$, it was evaporated under vacuum to obtain the crude product. It was further purified by silica gel column chromatography using DCM/hexane (1:1) as eluent and washing with hexane. The product was obtained as bright yellowish-orange solid in $35 \%$ yield $(320 \mathrm{mg}) .{ }^{1} \mathrm{H} \mathrm{NMR}\left(300 \mathrm{MHz}, \mathrm{CDCl}_{3}\right)$ : $\delta 8.98(\mathrm{~s}, 1 \mathrm{H}), 7.90(\mathrm{~m}, 4 \mathrm{H}), 7.74(\mathrm{~d}, 1 \mathrm{H}, \mathrm{J}=8.7 \mathrm{~Hz}), 7.06(\mathrm{~s}, 1 \mathrm{H}), 6.91(\mathrm{~m}, 5 \mathrm{H}), 6.54(\mathrm{~s}, 1 \mathrm{H}), 4.06$ $(\mathrm{m}, 4 \mathrm{H}), 1.88-1.81(\mathrm{~m}, 4 \mathrm{H}), 1.31(\mathrm{~m}, 20 \mathrm{H}), 0.9(\mathrm{~m}, 6 \mathrm{H}) .{ }^{13} \mathrm{C} \mathrm{NMR}\left(75 \mathrm{MHz}, \mathrm{CDCl}_{3}\right): 177.38$ $176.34,161.91,161.45,161.35,150.57,150.23,147.78,145.01,140.51,139.27,133.03,131.42$, $131.05,128.81,128.73,124.95,119.21,118.69,117.37,115.65,114.19,114.16,95.26,68.22$, 68.17, 31.86, 29.44, 29.30, 26.10, 22.70, 14.14. Calculated for $\mathrm{C}_{40} \mathrm{H}_{47} \mathrm{Br}_{2} \mathrm{NO}_{4} \mathrm{PtS}$ 992.77, found $\operatorname{ESI-MS~(m/z):~} 1016.10[\mathrm{M}+\mathrm{Na}]^{+}$.

\section{General procedure for synthesis of Metal complexes (Example-Iin-C18-Pt(acac))}

In a flame dried flask, Iin-C18-boronate ester (0.075 g, $0.07 \mathrm{mmol}), \mathbf{P t}(\mathbf{a c a c})-\mathbf{O c t y l}(0.13$ $\mathrm{g}, 0.14 \mathrm{mmol}), \mathrm{Pd}_{2}(\mathrm{dba})_{3}\left(3.2 \mathrm{mg}, 3.5 \times 10^{-3} \mathrm{mmol}\right), \mathrm{Pd}\left(\mathrm{P}^{\mathrm{t}} \mathrm{Bu}_{3}\right)_{2}\left(3.6 \mathrm{mg}, 6.97 \times 10^{-3} \mathrm{mmol}\right)$ were combined and vacuum-argon cycled for three times to remove the oxygen from the reaction medium. In the meantime, $\mathrm{K}_{3} \mathrm{PO}_{4}(0.088 \mathrm{~g}, 0.42 \mathrm{mmol})$ was dissolved in $2 \mathrm{~mL}$ of Millipore water and deoxygenated by purging argon for 1 hour. Dry THF $(18 \mathrm{~mL})$ was added to the reaction mixture and the dark brown reaction mixture was stirred for 15 minutes. Aqueous $\mathrm{K}_{3} \mathrm{PO}_{4}$ solution was added to the reaction mixture and the color of the reaction mixture immediately turned into dark blue color. It was heated to $60^{\circ} \mathrm{C}$ and stirred under argon atmosphere overnight. After the consumption of the boronate ester, the reaction mixture was cooled down to room temperature. 
The solvents were stripped off under vacuum and the crude product was extracted with dichloromethane. It was dried with anhydrous $\mathrm{Na}_{2} \mathrm{SO}_{4}$, filtered and the solvent was evaporated to obtain the crude product. It was further purified by silica gel column chromatography with DCM/hexane (60/40) as eluent mixture to obtain a dark solid. It was dissolved into minimum amount of DCM and methanol was added to obtain a precipitate. It was isolated by vacuum filtration, washed with methanol, and dried to obtain the product as a dark blue solid (90 mg, 53\% yield).

Iin-C18-Pt(acac): ${ }^{1} \mathrm{H}$ NMR (500 MHz, $\left.\mathrm{CD}_{2} \mathrm{Cl}_{2}\right): \delta 9.17(\mathrm{~d}, 1 \mathrm{H}, \mathrm{J}=8.3 \mathrm{~Hz}), 8.88(\mathrm{~d}, 1 \mathrm{H}, \mathrm{J}=5.6$ Hz), $8.06\left(\mathrm{dd}, 5 \mathrm{H}, \mathrm{J}_{1}=22.3 \mathrm{~Hz}, \mathrm{~J}_{2}=8.7 \mathrm{~Hz}\right), 7.63(\mathrm{t}, 1 \mathrm{H}, 6.3 \mathrm{~Hz}), 7.49(\mathrm{~s}, 1 \mathrm{H}), 7.33(\mathrm{~d}, 1 \mathrm{H}, 8.6$ Hz), $7.19(\mathrm{~d}, 1 \mathrm{H}, \mathrm{J}=7.7 \mathrm{~Hz}), 7.05(\mathrm{~m}, 5 \mathrm{H}), 6.94(\mathrm{t}, 1 \mathrm{H}, \mathrm{J}=6.2 \mathrm{~Hz}), 6.71(\mathrm{~s}, 1 \mathrm{H}), 4.1(\mathrm{~m}, 4 \mathrm{H}), 3.76$ $(\mathrm{d}, 2 \mathrm{H}, \mathrm{J}=6.3 \mathrm{~Hz}), 1.99(\mathrm{~m}, 1 \mathrm{H}), 1.89(\mathrm{~m}, 4 \mathrm{H}), 1.34(\mathrm{~m}, 52 \mathrm{H}), 0.96(\mathrm{~m}, 6 \mathrm{H}), 0.86(\mathrm{t}, 6 \mathrm{H}, \mathrm{J}=6.9$ Hz). ${ }^{13} \mathrm{C}$ NMR (75 MHz, $\left.\mathrm{CDCl}_{3}\right): \delta 177.58,176.54,168.73,163.63,161.49,161.37,147.11$, $146.89,146.24,145.33,139.71,137.92,137.50,132.26,131.23,130.95,130.20,128.83,128.74$ $127.35,121.22,119.00,118.36,117.27,114.32,104.93,95.11,68.29,68.21,44.64,36.68,31.98$ 31.96, 31.90, 31.87, 29.53, 29.45, 29.43, 29.34, 29.30, 26.10, 22.73, 22.70, 14.12. CHN Analysis: Calcd for $\mathrm{C}_{136} \mathrm{H}_{184} \mathrm{~N}_{4} \mathrm{O}_{10} \mathrm{Pt}_{2} \mathrm{~S}_{2}$ : C, 65.62; H, 7.45; N, 2.25. Found: C, 65.63; H, 7.26; N, 2.34.

Iin-C8-Pt(acac): ${ }^{1} \mathrm{H}$ NMR $\left(500 \mathrm{MHz}, \mathrm{CDCl}_{3}\right): \delta 9.13(\mathrm{~d}, 1 \mathrm{H}, \mathrm{J}=8.3 \mathrm{~Hz}), 8.86(\mathrm{~d}, 1 \mathrm{H}, \mathrm{J}=5.5 \mathrm{~Hz})$, $8.01\left(\mathrm{dd}, 4 \mathrm{H}, \mathrm{J}_{1}=25.4 \mathrm{~Hz}, \mathrm{~J}_{2}=8.7 \mathrm{~Hz}\right), 7.57(\mathrm{t}, 1 \mathrm{H}, 5.7 \mathrm{~Hz}), 7.47(\mathrm{~s}, 1 \mathrm{H}), 7.31(\mathrm{~d}, 1 \mathrm{H}, \mathrm{J}=8.3 \mathrm{~Hz})$ $7.15(\mathrm{~d}, 1 \mathrm{H}, 7.9 \mathrm{~Hz}), 7.02(\mathrm{~m}, 5 \mathrm{H}), 6.88(\mathrm{t}, 1 \mathrm{H}, \mathrm{J}=6.5 \mathrm{~Hz}), 6.65(\mathrm{~s}, 1 \mathrm{H}), 4.11(\mathrm{t}, 2 \mathrm{H}, 6.5 \mathrm{~Hz}), 4.05$ (t, 2H, $6.6 \mathrm{~Hz}), 3.76(\mathrm{~d}, 2 \mathrm{H}, \mathrm{J}=6.1 \mathrm{~Hz}), 1.92(\mathrm{~m}, 5 \mathrm{H}), 1.50-1.36(\mathrm{~m}, 28 \mathrm{H}), 1.02(\mathrm{t}, 3 \mathrm{H}, 7.6 \mathrm{~Hz})$ 0.93 (m, 9H). ${ }^{13} \mathrm{C}$ NMR (75 MHz, $\left.\mathrm{CDCl}_{3}\right): \delta 168.73,163.59,161.45,138.01,137.59,132.21$, $131.03,128.83,128.75,128.74,128.70,121.20,114.24,68.27,68.03,37.78,31.88,30.91,29.73$, $29.48,29.44,29.29,28.92,29.13,26.09,24.34,23.16,22.71,22.69,14.21,14.13,10.92$ (some of 
the peaks in the aromatic region were not observed due to low solubility of this complex). CHN Analysis: Calcd for $\mathrm{C}_{112} \mathrm{H}_{136} \mathrm{~N}_{4} \mathrm{O}_{10} \mathrm{Pt}_{2} \mathrm{~S}_{2}$ : C, 62.49; H, 6.37; N, 2.60. Found: C, 62.17; H, 6.46; N, 2.79. MALDI-TOF MS (m/z) [M] $]^{+}$Calcd for $\mathrm{C}_{112} \mathrm{H}_{126} \mathrm{~N}_{4} \mathrm{O}_{10} \mathrm{Pt}_{2} \mathrm{~S}_{2} 2152.9084$, found 2152.9084 .

\section{Synthesis of Iin-C18-Poly}

In a $10 \mathrm{~mL}$ Schlenk tube, Iin-C18-boronate ester (0.05 g, $0.05 \mathrm{mmol}), 11$ (0.046 g, 0.05 $\mathrm{mmol}), \mathrm{Pd}_{2}(\mathrm{dba})_{3}\left(2.13 \mathrm{mg}, 2.33 \times 10^{-3} \mathrm{mmol}\right), \mathrm{Pd}\left(\mathrm{P}^{\mathrm{t}} \mathrm{Bu}_{3}\right)_{2}\left(2.4 \mathrm{mg}, 4.65 \times 10^{-3} \mathrm{mmol}\right)$ were combined and vacuum-argon cycled for three times to remove the oxygen from the reaction medium. Dry THF (4 mL) was added via syringe through the septum. Previously deoxygenated aqueous $\mathrm{K}_{3} \mathrm{PO}_{4}$ solution $(0.06 \mathrm{~g}, 0.3 \mathrm{mmol}$ in $1 \mathrm{~mL}$ of Millipore water) was added to the reaction mixture under argon atmosphere. It was heated to $60^{\circ} \mathrm{C}$ and stirred under argon for 48 hours. After the reaction, it was cooled down to room temperature and poured it over vigorously stirred methanol. The precipitate was isolated and transferred to a Soxhlet thimble. The crude polymer was purified via Soxhlet extraction with methanol and hexane to remove low molecular weight species and residual catalyst. Finally, the polymer was extracted with chloroform, reduced in volume and poured over vigorously stirred methanol. The precipitate was collected via vacuum filtration to obtain the polymer as dark green fibrous solid $(25 \mathrm{mg})$. Gel permeation chromatography of the polymer in THF was difficult due comparatively low solubility of the polymer. Gel permeation chromatography showed chromatograms with a long tail, consistent with non-ideal interaction of the polymer with the size-exclusion support. Analysis of the non-ideal GPC traces gave $\mathrm{M}_{\mathrm{n}} \sim 3300$ and $\mathrm{M}_{\mathrm{w}} \sim 11400$ (PDI 3.5). We believe that the $\mathrm{M}_{\mathrm{n}}$ is a lower limit

for the true value due to the non-ideal GPC behavior. The ${ }^{1} \mathrm{H}$ NMR of this polymer was obtained in chloroform (see Figure S13). 


\section{NMR spectra}

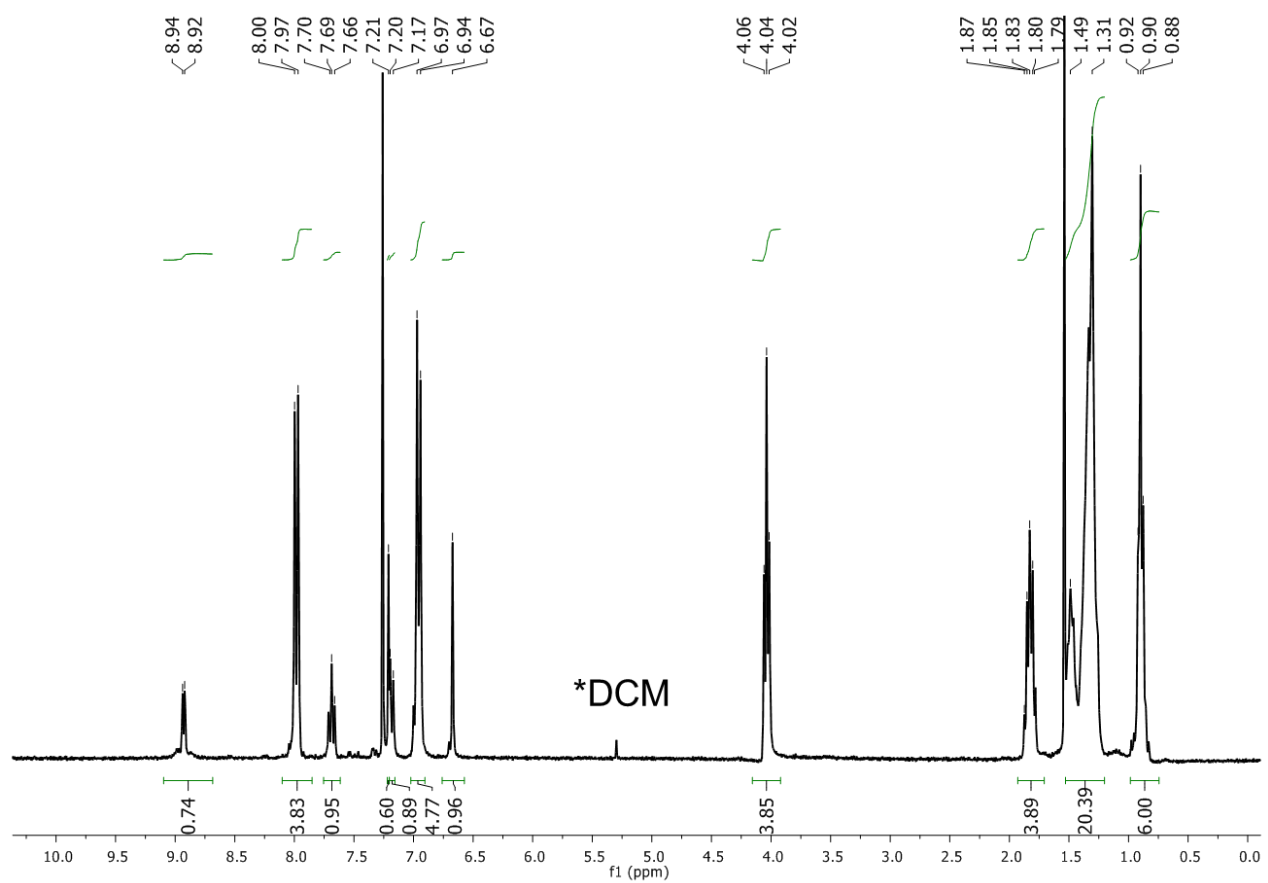

Figure S1. ${ }^{1} \mathrm{H}$ NMR spectra of Pt(acac)-Octyl in $\mathrm{CDCl}_{3}$.
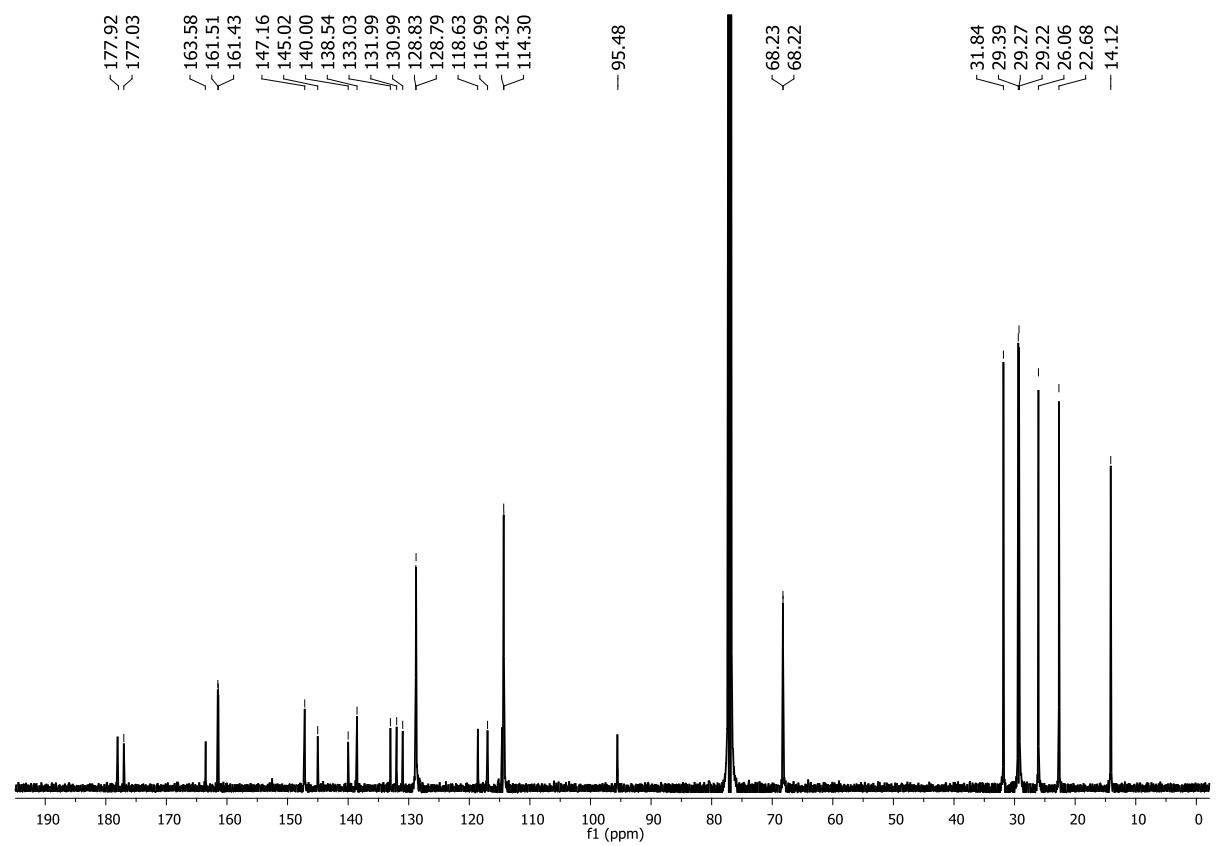

Figure S2. ${ }^{13} \mathrm{C}$ NMR spectra of $\mathbf{P t}\left(\right.$ acac)-Octyl in $\mathrm{CDCl}_{3}$. 


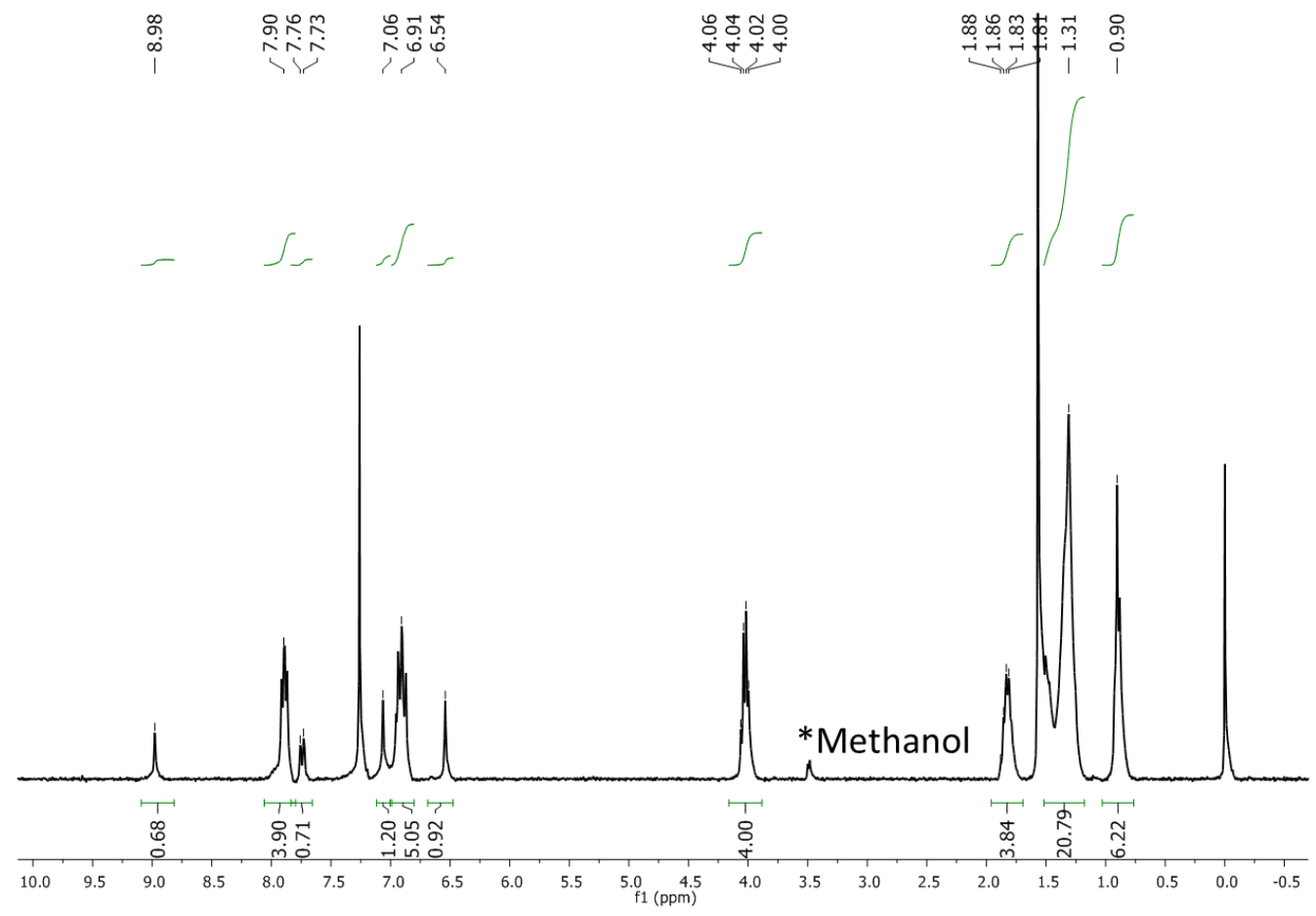

Figure S3. ${ }^{1} \mathrm{H}$ NMR spectra of $\mathbf{1 1}$ in $\mathrm{CDCl}_{3}$.
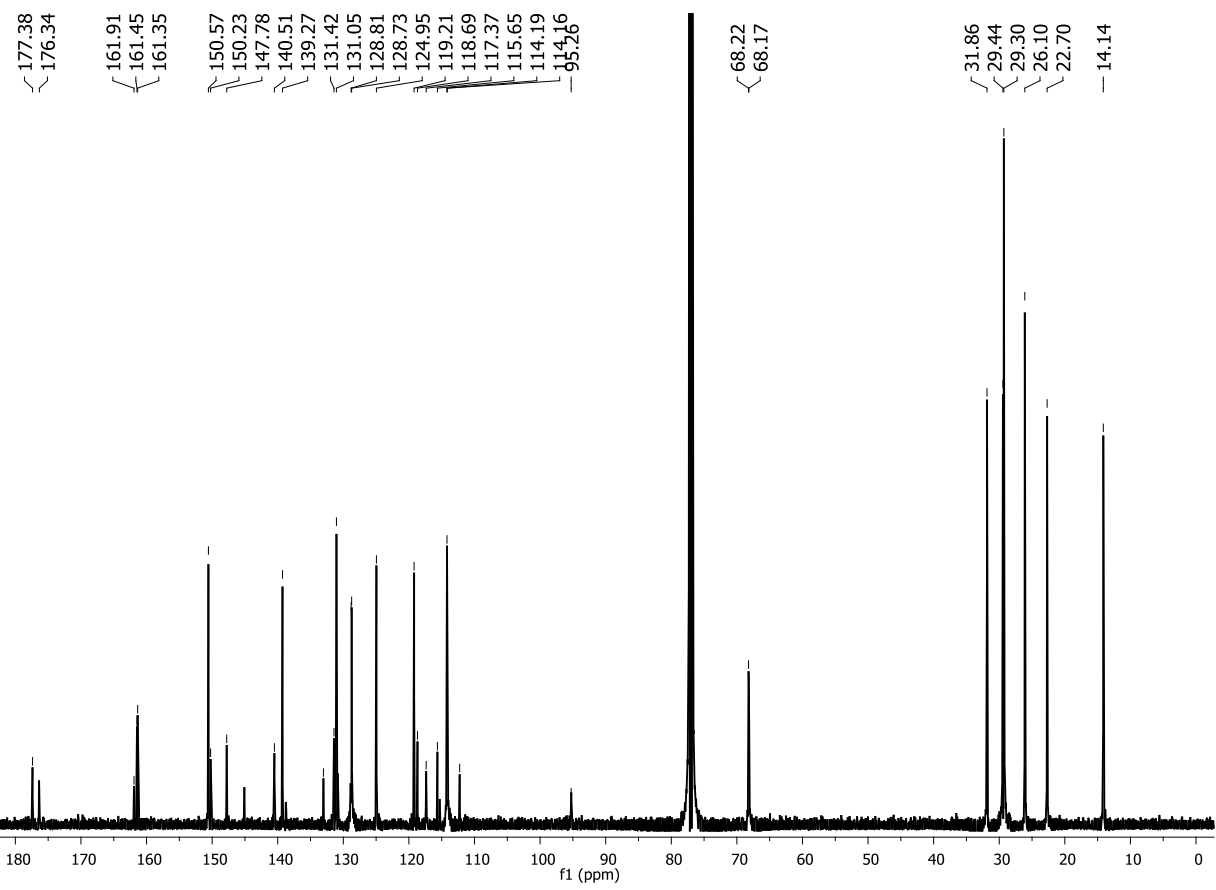

Figure S4. ${ }^{13} \mathrm{C}$ NMR spectra of $\mathbf{1 1}$ in $\mathrm{CDCl}_{3}$. 


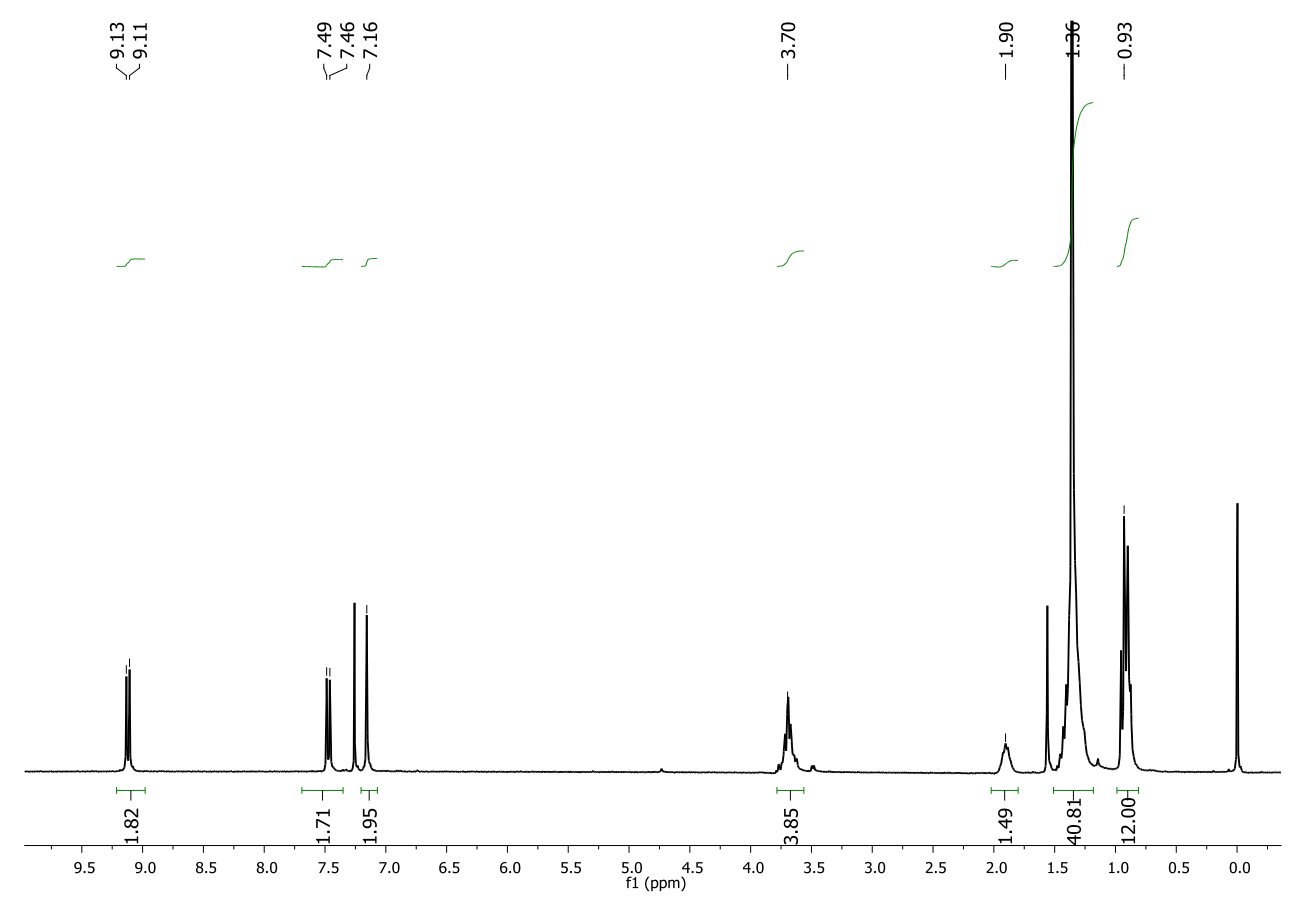

Figure S5. ${ }^{1} \mathrm{H}$ NMR spectra of Iin-C8-Boronate ester in $\mathrm{CDCl}_{3}$.

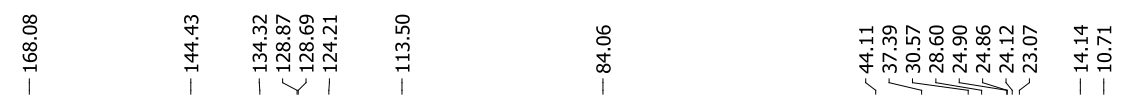

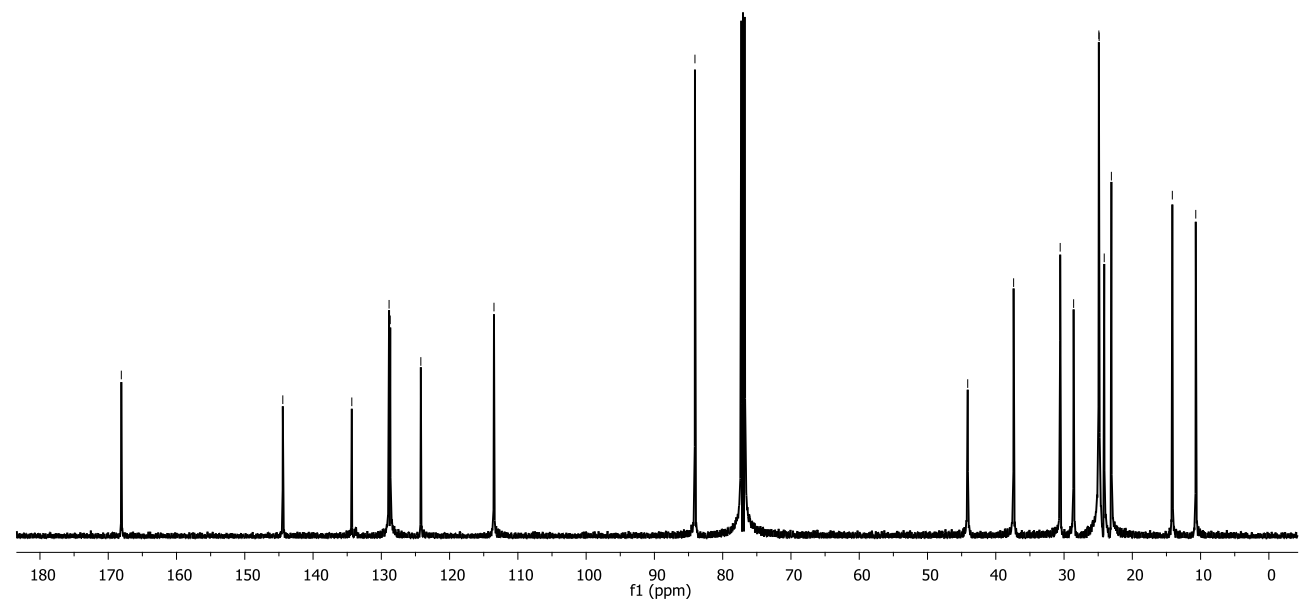

Figure S6. ${ }^{13} \mathrm{C}$ NMR spectra of Iin-C8-Boronate ester in $\mathrm{CDCl}_{3}$. 


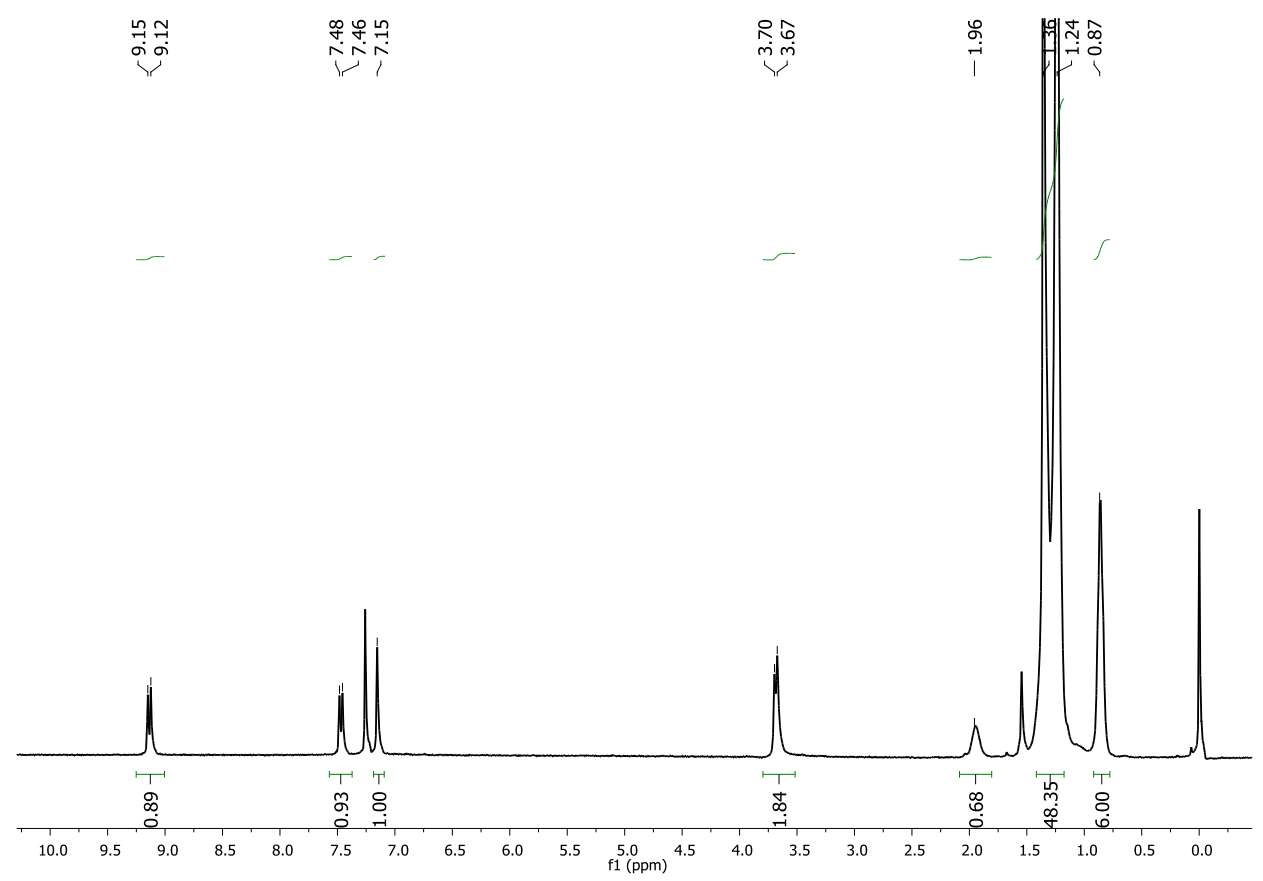

Figure S7. ${ }^{1} \mathrm{H}$ NMR spectra of Iin-C18-Boronate ester.

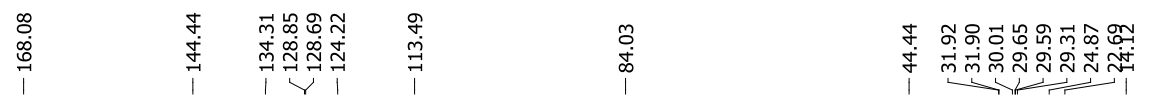

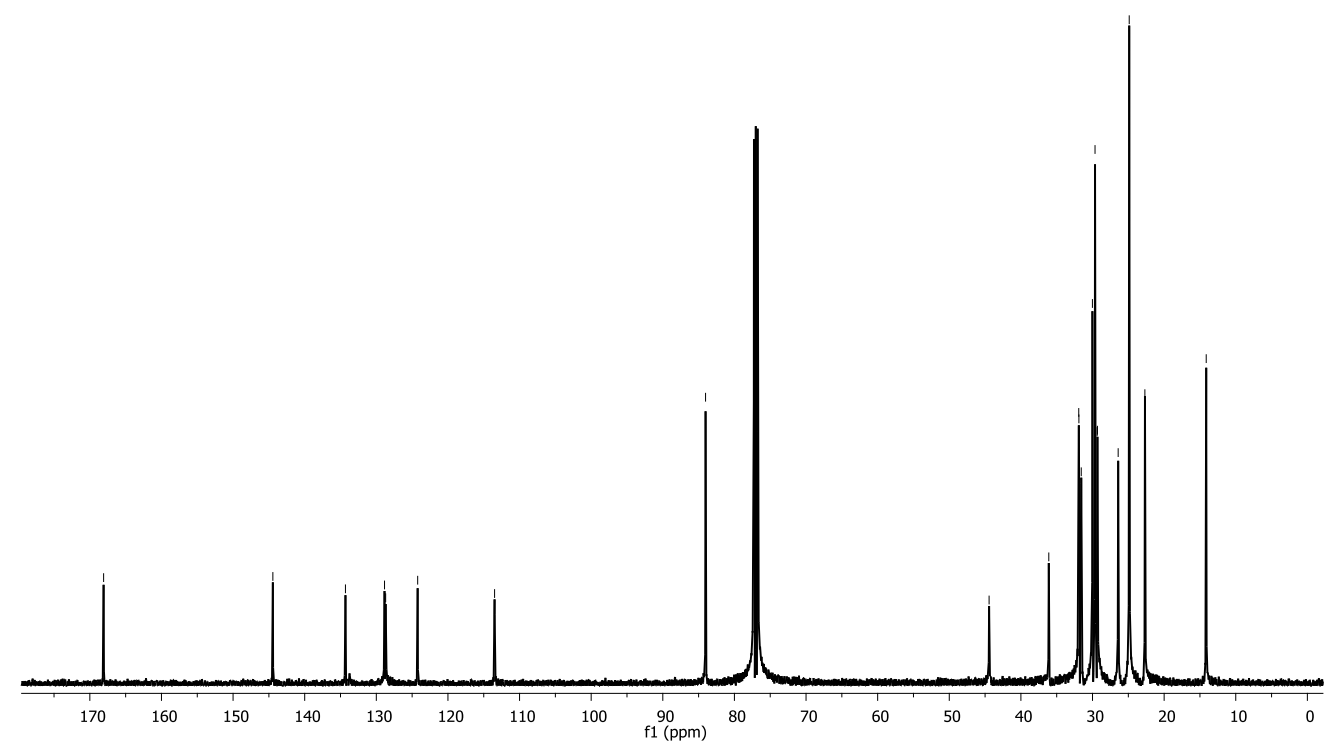

Figure S8. ${ }^{13} \mathrm{C}$ NMR spectra of Iin-C18-Boronate ester in $\mathrm{CDCl}_{3}$. 


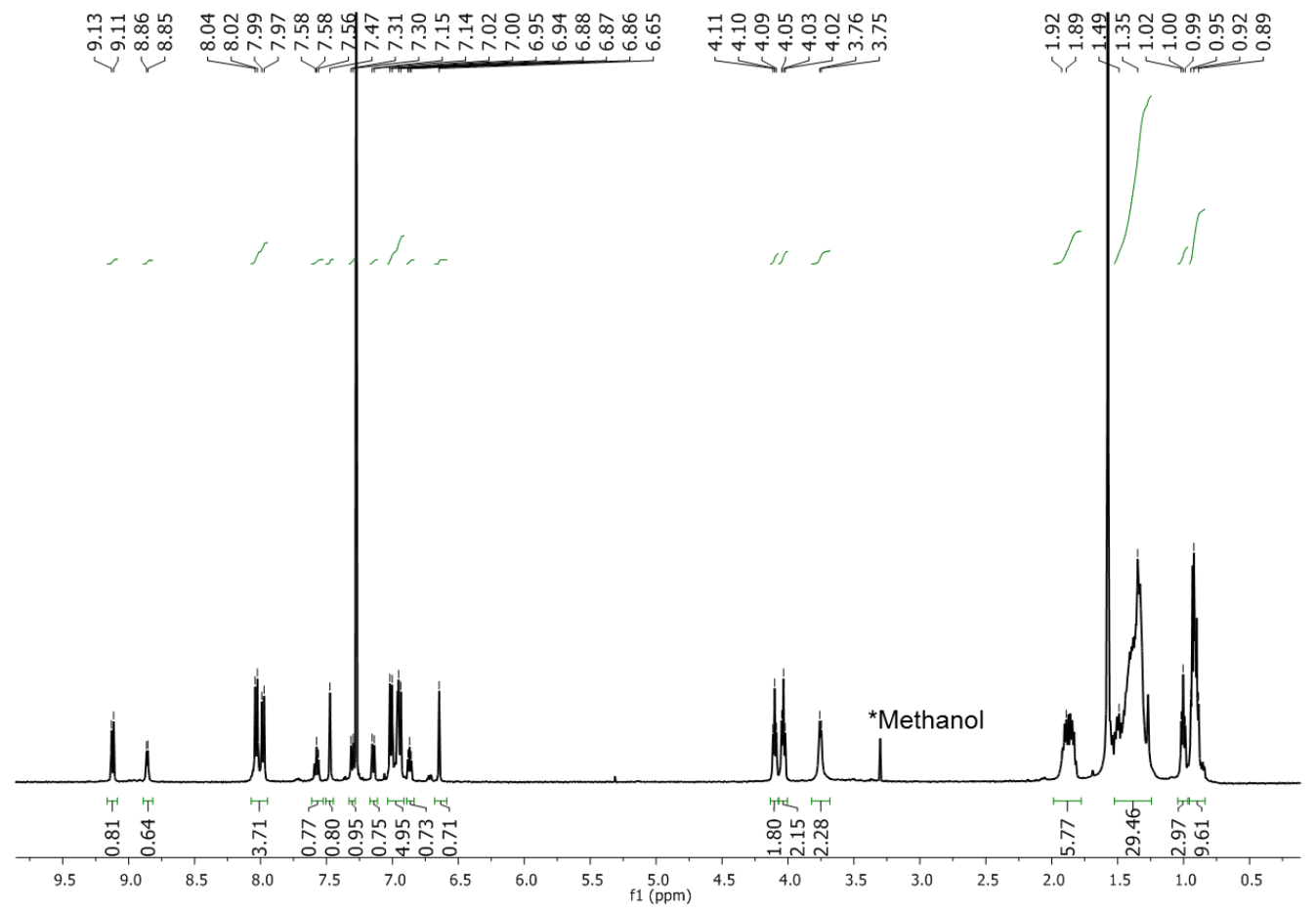

Figure S9. ${ }^{1} \mathrm{H}$ NMR spectra of Iin-C8-Pt(acac) in $\mathrm{CDCl}_{3}$.

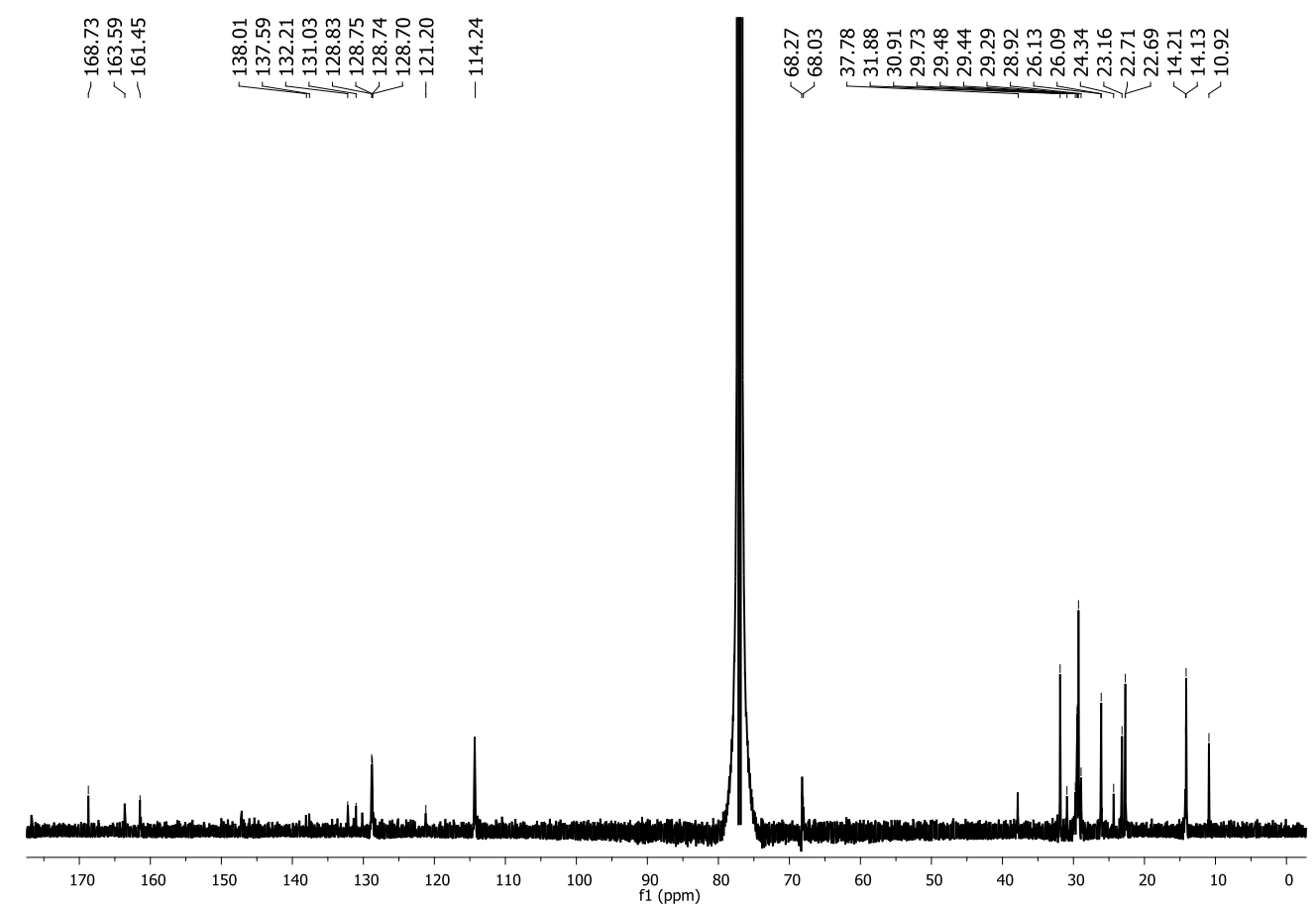

Figure S10. ${ }^{13} \mathrm{C}$ NMR spectra of Iin-C18-Pt(acac) in $\mathrm{CDCl}_{3}$. 


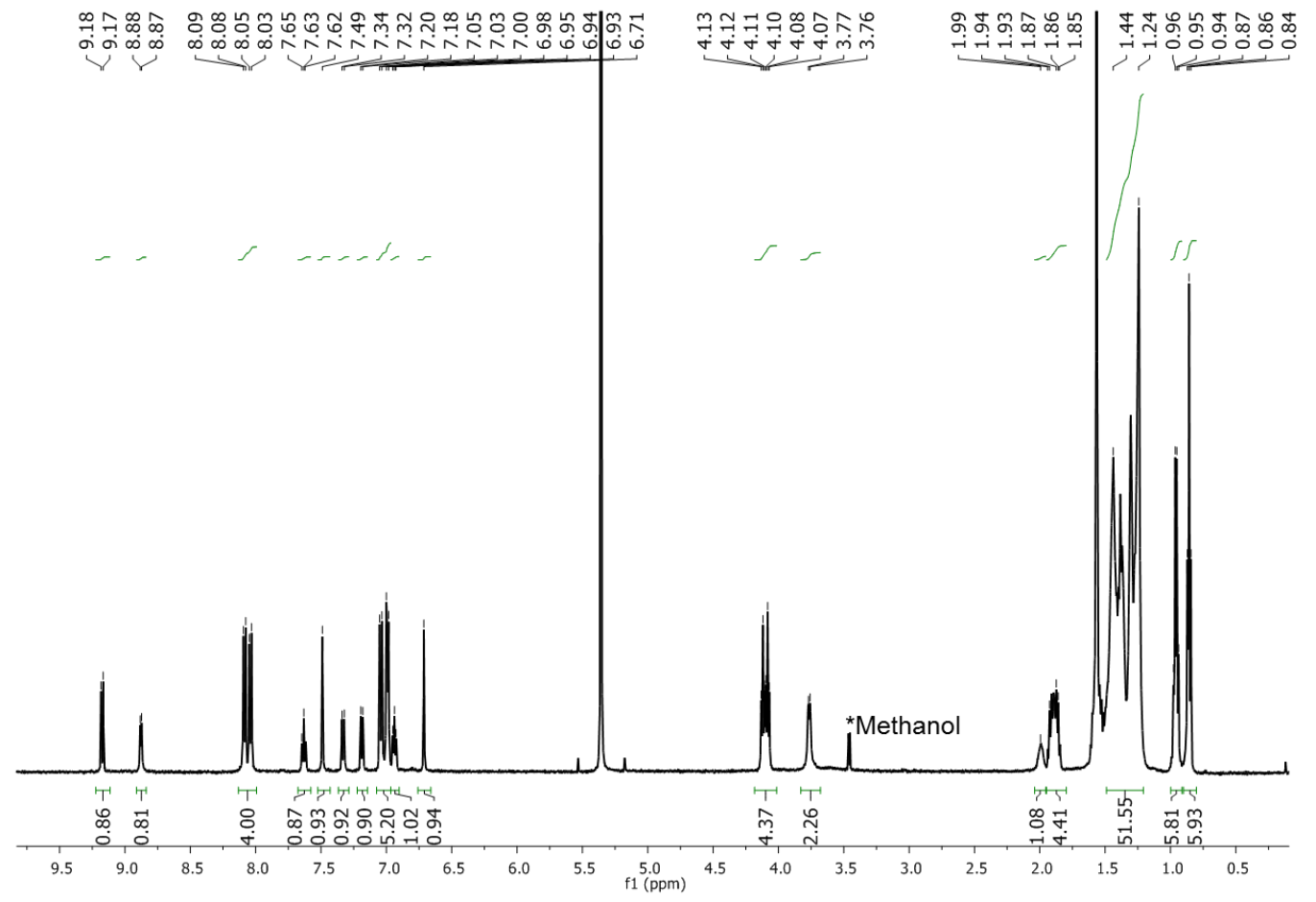

Figure S11. ${ }^{1} \mathrm{H}$ NMR spectra of Iin-C18-Pt(acac) in $\mathrm{CD}_{2} \mathrm{Cl}_{2}$.

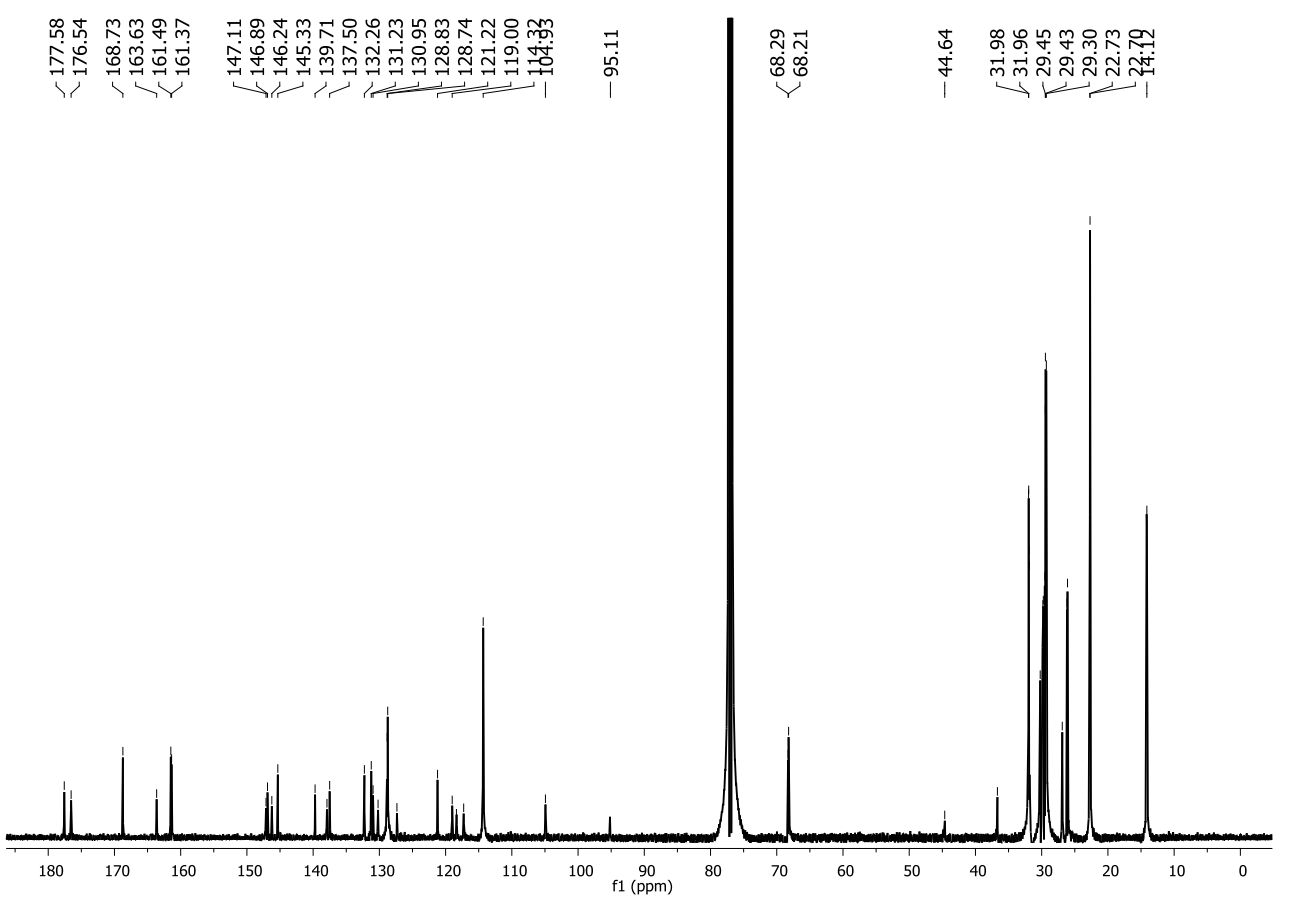

Figure S12. ${ }^{13} \mathrm{C}$ NMR spectra of Iin-C18-Pt(acac) in $\mathrm{CDCl}_{3}$. 


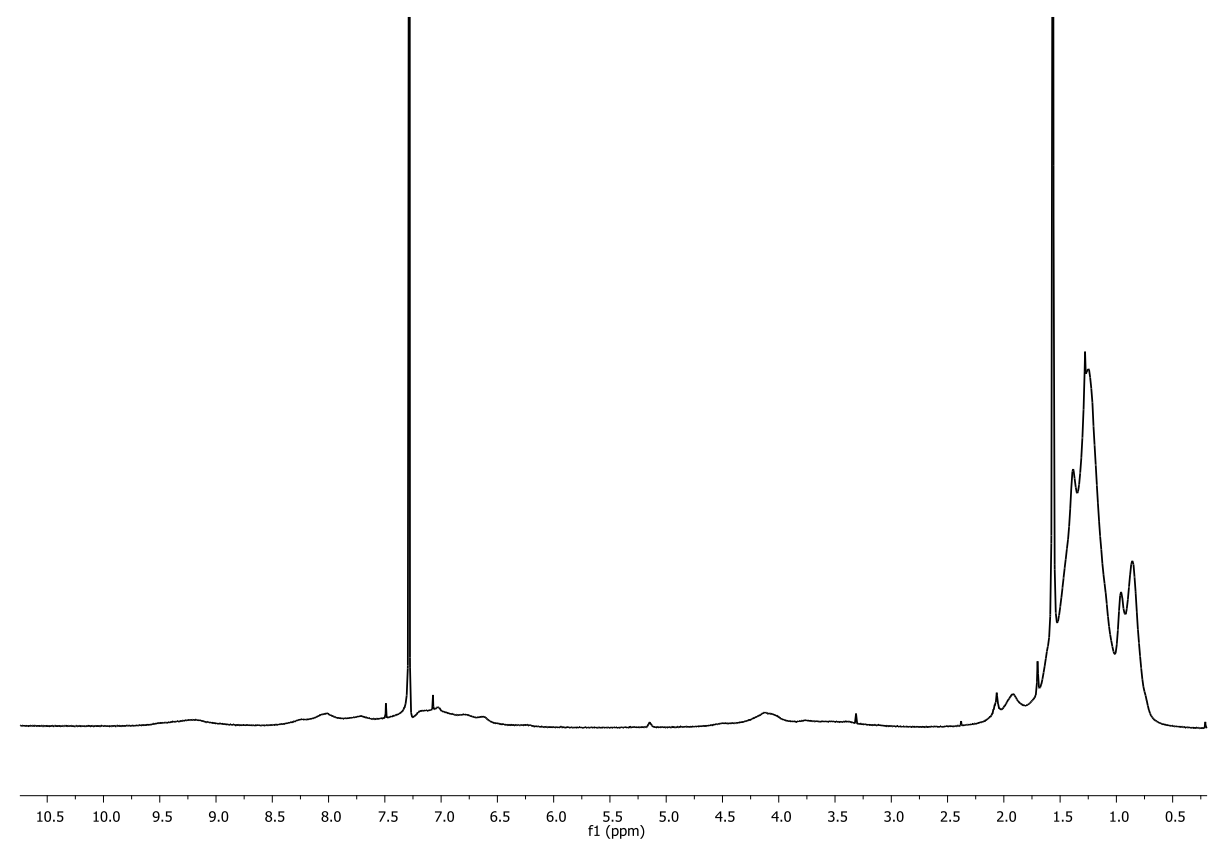

Figure S13. ${ }^{1} \mathrm{H}$ NMR spectra of Iin-C18-Poly in $\mathrm{CHCl}_{3}$.

\section{Computational study.}
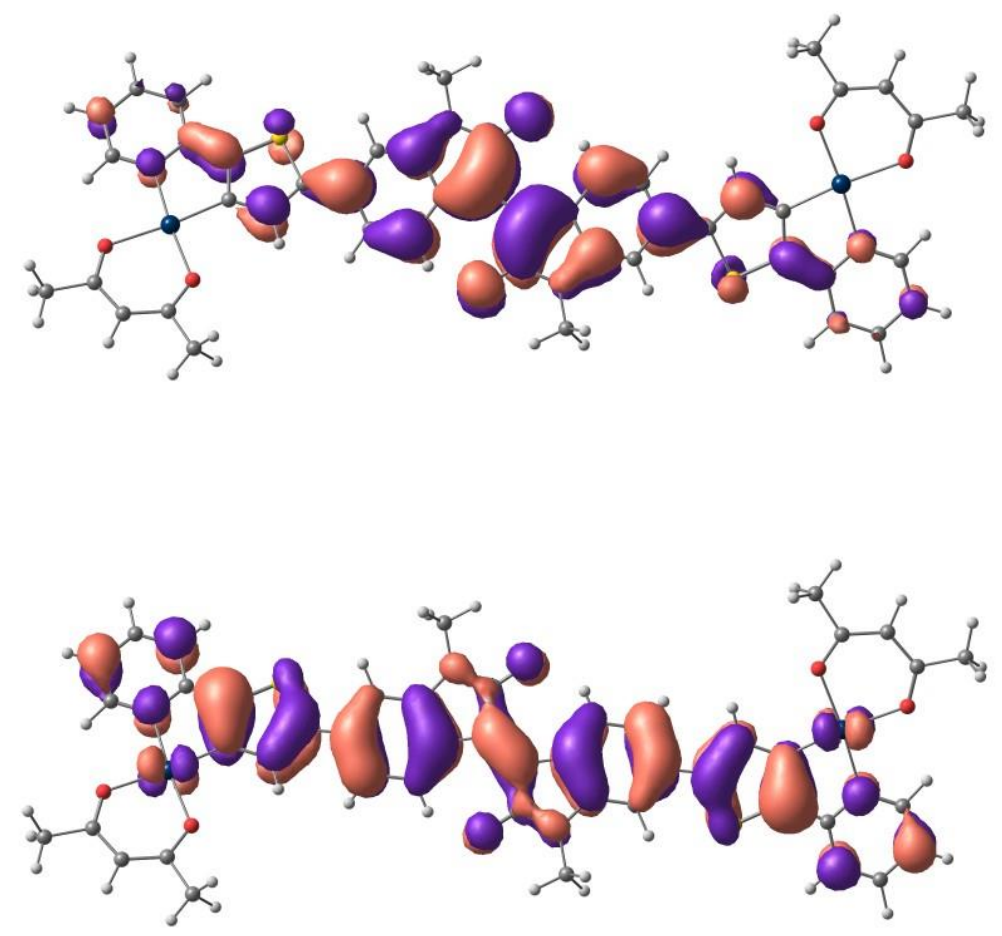

Figure S14. Molecular Orbitals for the LUMO (top), and HOMO (bottom) of Iso-Pt-(acac)'. Orbitals are imaged with an isovalue of 0.02 . 


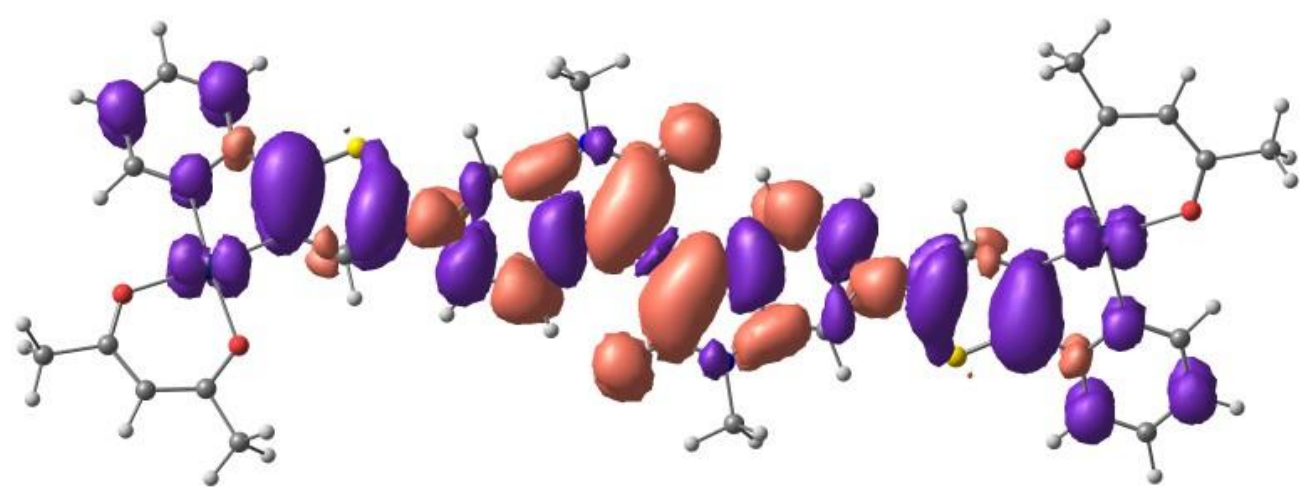

Figure S15. Charge Difference Density (CDD) for the singlet electronic transition predicted at $627.8 \mathrm{~nm}$ for Iso-Pt-(acac)'. Blue coloring indicates electron density being lost, while red coloring indicates electron density being gained. CDD plot was imaged with an isovalue of 0.0004 .

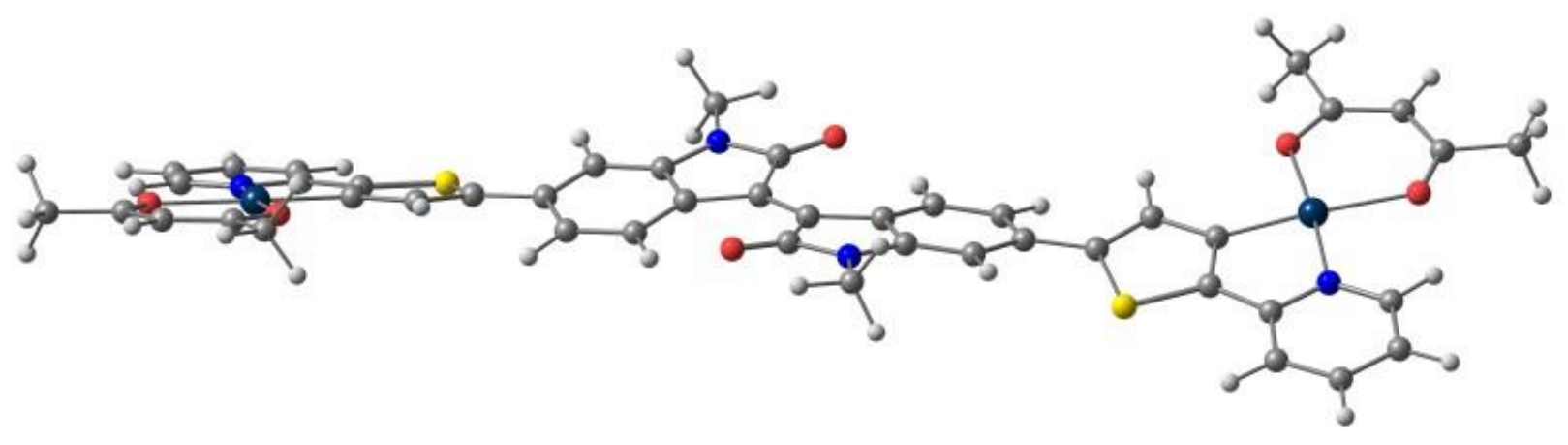

Figure S16. DFT optimized singlet ground state structure of Iso-Pt-(acac)'. 


\section{Electrochemical studies}

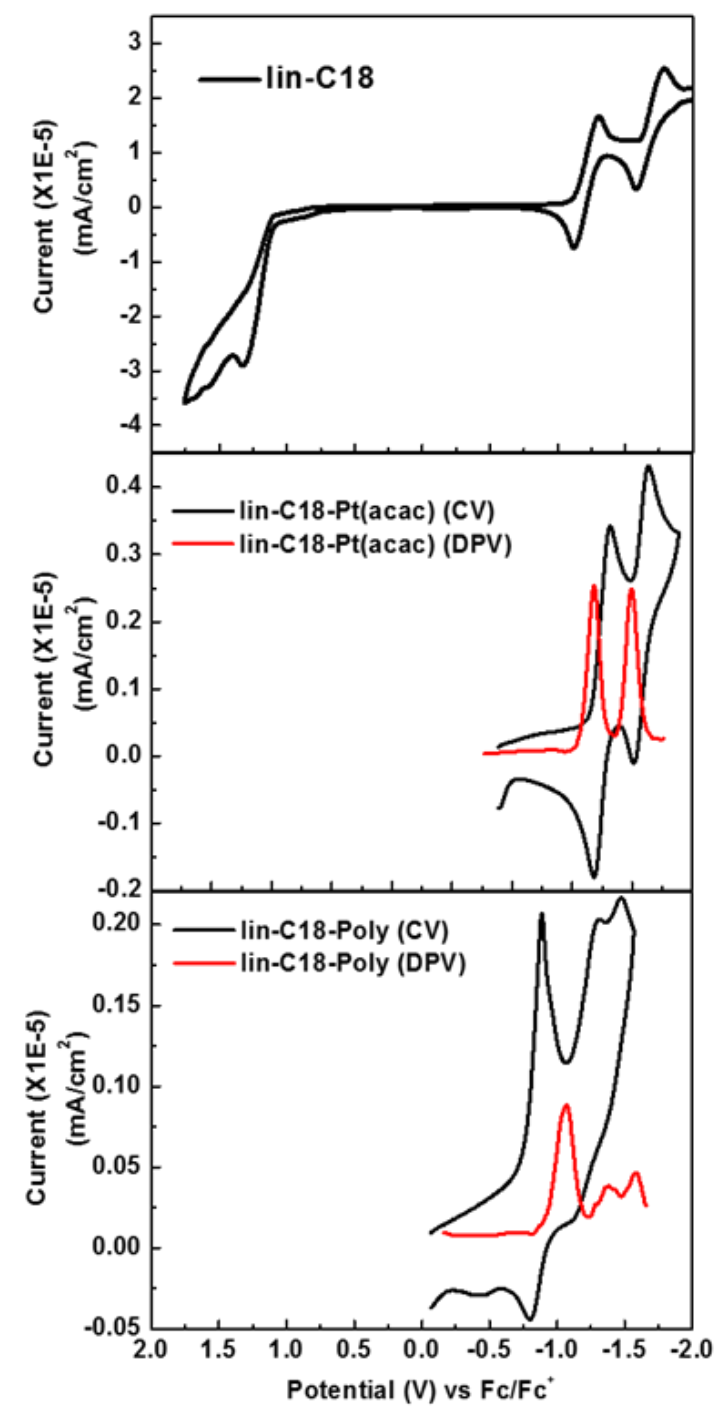

Figure S17. Solution electrochemistry and reduction DPVs of isoindigo chromophores in $0.1 \mathrm{M}$ $\mathrm{NBu}_{4} \mathrm{PF}_{6}$ in DCM with $0.1 \mathrm{M}$ TBAPF6 as the supporting electrolyte. It was scanned at $100 \mathrm{mVs}^{-}$ ${ }^{1}$. All the potentials are referenced to $\mathrm{Fc} / \mathrm{Fc}^{+}$couple as an internal standard. 


\section{References}

(1) Clem, T. A.; Kavulak, D. F. J.; Westling, E. J.; Fréchet, J. M. J. Cyclometalated Platinum Polymers: Synthesis, Photophysical Properties, and Photovoltaic Performance. Chem. Mater. 2010, 22, 1977-1987.

(2) Goswami, S.; Winkel, R. W.; Alarousu, E.; Ghiviriga, I.; Mohammed, O. F.; Schanze, K. S. Photophysics of Organometallic Platinum(II) Derivatives of the Diketopyrrolopyrrole Chromophore. J. Phys. Chem. A 2014, 118, 11735-11743.

(3) Liao, C.-Y.; Chen, C.-P.; Chang, C.-C.; Hwang, G.-W.; Chou, H.-H.; Cheng, C.-H. Synthesis of Conjugated Polymers Bearing Indacenodithiophene and Cyclometalated Platinum(II) Units and their Application in Organic Photovoltaics. Sol. Energy Mater. Sol. Cells 2013, 109, 111-119.

(4) Mei, J.; Graham, K. R.; Stalder, R.; Reynolds, J. R. Synthesis of Isoindigo-Based Oligothiophenes for Molecular Bulk Heterojunction Solar Cells. Org. Lett. 2010, 12, 660-663.

(5) Zhang, G.; Fu, Y.; Xie, Z.; Zhang, Q. Synthesis and Photovoltaic Properties of New Low Bandgap Isoindigo-Based Conjugated Polymers. Macromolecules 2011, 44, 1414-1420. 